\title{
ЭФФЕКТИВНОСТЬ ОБУЧЕНИЯ ТАКТИЧЕСКОЙ ПОДГОТОВКИ КИКБОКСЕРОВ В РАЗДЕЛЕ ПОИНТФАЙТИНГ
}

\section{EFFICIENCY OF TACTICAL TRAINING OF KICKBOXERS IN THE SECTION OF POINTFIGHTING}

A. Poteryakhin

V. Kondakov

Summary: This article presents the results of a study aimed at developing an effective methodology for training athletes in kickboxing in the pointfighting section. To achieve a given goal, a battery of corresponding methods was used, among them: 1) analysis of scientific and information sources on the research problem;2) pedagogical observation;3) testing;4) methods of static and mathematical processing of recorded data, with the aim of their subsequent interpretation. Three educational organizations of the city of Belgorod acted simultaneously as a base corresponding to the purpose of the study. The participants of the experimental part of the study included kickboxers whose sports training was carried out from 2011 to 2021. The results recorded during the performance of the athletes participating in the experimental part of this study clearly demonstrated the effectiveness of the author's training program, reflected in winning 14 gold medals at the Russian championship, 10 gold medals at the Russian Cup, 10 gold medals at the European Cup, 8 gold medals from the World Cup and gold from the world tournament.

Keywords: kickboxing, tactical training, pointfighting, competitions.
Потеряхин Алексей Андреевич

ФГАОУ ВО «Белгородский государственный национальный исследовательский университет»

Kingmickey@mail.ru

Кондаков Виктор Леонидович

Д.п.н., профессор, ФГАОУ ВО «Белгородский государственный национальный исследовательский университет»

kondakov@bsu.edu.ru

Аннотация: В данной статье представлены результаты исследования, целью которого стала разработка действенной методики подготовки спортсменов в kickboxing в разделе pointfighting. Для достижение заданной цели была задействована батарея соответствующей ей методов, среди них: 1) анализ научно-информационных источников по проблеме исследования; 2) педагогическое наблюдение; 3) тестирование; 4) методы статико-математической обработки фиксируемых данных, с целью последующей их интерпретацией.. В качестве базы, соответствующей цели исследования, выступили одновременно три образовательных организаций города Белгорода. В состав участников опытно-экспериментальной части исследования вошли кикбоксеры, спортивная подготовка которых осуществлялась с 2011 по 2021 гг. Результаты, зафиксированные в ходе выступления спорстменов - участников опытно-экспериментальной части настоящего исследования, наглядно продемонстрировали результативность авторской программы подготовки, отразившись в завоевании 14 золотых медалей на первенстве России, 10 золотых медалей на кубке России, 10 золотых медалей на кубке Европы, 8 золотых медалей с кубка Мира и золото с мирового турнира.

Ключевые слова: кикбоксинг, тактическая подготовка, поинтфайтинг, соревнования.

объединяющий в себе некоторые элементы тхэквондо и каратэ [7, с.56]. Основной задачей спортсмена, который выступает в рамках раздела pointfighting, является нанесение результативного удара голову в ходе поединка с соперником, что признано менее опасным, по сравнению с остальными разделами, в которых место удара может варьировать, увеличивая травмируемой пространство [5, с.23]. Популярность pointfighting обусловлена возможностью проведения открытых, доступных для обозрения зрелищных поединков, а также отсутствием ограничений желающих заниматься этим видом спорта, ни по возрасту, ни по половой принадлежности.

Для достижения заданной темой исследования цели исследовании - разработки действенной методики подготовки спортсменов в kickboxing в разделе pointfighting, была задействована батарея соответствующей цели методов, среди них: 1) анализ научно-информационных источников по проблеме исследования; 2) педагогическое наблюдение; 3) тестирование; 4) методы статико-матема- 
тической обработки фиксируемых данных, с целью последующей их интерпретацией.

В качестве базы, соответствующей цели исследования, выступили одновременно три образовательных организаций: МБУДО БДДТ, МБОУ ЛИЦЕЙ №9, МБОУ СОШ № 21 г. Белгорода. В состав участников опытно-экспериментальной части исследования вошли кикбоксеры, спортивная подготовка которых осуществлялась с 2011 по 2021 гг.

Эффективные атакующие, контратакующие действия и работа против ног в разделе поинтфайтинг

\begin{tabular}{|c|c|c|c|}
\hline № & Атакующие действия & Контратакующие действия & Работа против ног \\
\hline 1 & Удар передней рукой & Удар передней рукой против атаки задней рукой & Постановка передней ноги \\
\hline 2 & Удар задней рукой & Удар задней рукой против атаки передней рукой & $\begin{array}{l}\text { Опережение соперника при ударе передней } \\
\text { ногой }\end{array}$ \\
\hline 3 & Блиц с передней руки & Удар рукой в корпус против атаки передней рукой & Уход за спину против передней ноги \\
\hline 4 & Блиц с задней руки & Задней рукой в корпус - передней рукой в голову & Накладка на переднюю ногу \\
\hline 5 & Сайд-кик & Передней рукой в голову - задней рукой в корпус & Нырок против передней ноги \\
\hline 6 & Сайд-кик - удар передней рукой & Сайд-кик против атаки передней рукой & Уход с линии атаки против передней ноги \\
\hline 7 & $\begin{array}{l}\text { Блиц с передней руки в корпус - задней рукой } \\
\text { в голову }\end{array}$ & Встречная нога с разворота & $\begin{array}{l}\text { Накладка на переднюю ногу - удар задней } \\
\text { рукой - удар передней рукой }\end{array}$ \\
\hline 8 & Три сайд-кика - блиц с передней руки & Сайд-кик - удар передней рукой & Экс-кик - блиц с передней руки \\
\hline 9 & Три сайд-кика - блиц с задней руки & Удар передней рукой - сайд-кик & $\begin{array}{l}\text { Сайд-кик задней ногой с разворота - удар } \\
\text { задней рукой }\end{array}$ \\
\hline 10 & Экс-кик - сайд-кик - блиц с передней руки & Сайд-кик - два сайд-кика & $\begin{array}{l}\text { Хук-кик задней ногой с разворота - удар задней } \\
\text { рукой }\end{array}$ \\
\hline 11 & $\begin{array}{l}\text { Раунд-кик в корпус - раунд-кик в голову - } \\
\text { блиц с передней руки в корпус }\end{array}$ & Удар передней рукой - блиц с задней руки & $\begin{array}{l}\text { Накладка на переднюю ногу - сайд-кик - блиц } \\
\text { с передней руки }\end{array}$ \\
\hline 12 & $\begin{array}{l}\text { Хук-кик - раунд-кик - сайд-кик - блиц с } \\
\text { передней руки }\end{array}$ & Сайд-кик - блиц с передней руки - сайд-кик & $\begin{array}{l}\text { Накладка на переднюю ногу - удар передней } \\
\text { рукой - сайд-кик - удар задней рукой }\end{array}$ \\
\hline 13 & - & $\begin{array}{l}\text { Удар передней рукой - сайд-кик - блиц с перед- } \\
\text { ней руки }\end{array}$ & - \\
\hline 14 & - & Сайд-кик - блиц с задней руки & - \\
\hline 15 & - & Удар передней рукой - три сайд-кика & - \\
\hline 16 & - & $\begin{array}{l}\text { Сайд-кик - удар передней рукой - блиц с задней } \\
\text { руки }\end{array}$ & - \\
\hline
\end{tabular}

Методика обучения тактики ведения боя в разделе поинтфайтинг

\begin{tabular}{|c|c|c|c|c|c|c|c|}
\hline & ПН & BT & $\mathrm{CP}$ & ЧТ & ПТ & СБ & $B C$ \\
\hline Неделя 1 & $\begin{array}{c}\text { Атака - } \\
\text { без финтов }\end{array}$ & $\begin{array}{c}\text { Атака - } \\
\text { stop-and-go }\end{array}$ & $\begin{array}{c}\text { Атака - } \\
\text { финт ногой }\end{array}$ & Атака - выпад & $\begin{array}{c}\text { Атака - } \\
\text { вход в зону }\end{array}$ & Свободная работа & Выходной \\
\hline Неделя 2 & $\begin{array}{c}\text { Контратака - } \\
\text { без финтов }\end{array}$ & $\begin{array}{l}\text { Контратака - } \\
\text { stop-and-go }\end{array}$ & $\begin{array}{c}\text { Контратака - } \\
\text { финт ногой }\end{array}$ & $\begin{array}{c}\text { Контратака - вы- } \\
\text { пад } \\
\end{array}$ & $\begin{array}{c}\text { Контратака - } \\
\text { вход в зону }\end{array}$ & Свободная работа & Выходной \\
\hline Неделя 3 & $\begin{array}{c}\text { Работа против ноги } \\
\text { - без финтов }\end{array}$ & $\begin{array}{c}\text { Работа против } \\
\text { ноги - } \\
\text { stop-and-go }\end{array}$ & $\begin{array}{c}\text { Работа против } \\
\text { ноги - } \\
\text { финт ногой }\end{array}$ & $\begin{array}{c}\text { Работа против ноги } \\
\text { - выпад }\end{array}$ & $\begin{array}{c}\text { Работа против } \\
\text { ноги - } \\
\text { вход в зону }\end{array}$ & Свободная работа & Выходной \\
\hline Неделя 4 & Атака - все финты & Атака - все финты & $\begin{array}{c}\text { Контратака - все } \\
\text { финты }\end{array}$ & $\begin{array}{c}\text { Контратака - все } \\
\text { финты }\end{array}$ & $\begin{array}{c}\text { Работа против ноги } \\
\text { - все финты }\end{array}$ & $\begin{array}{c}\text { Работа против ноги } \\
\text { - все финты }\end{array}$ & Выходной \\
\hline Неделя 5 & Атака - все финты & $\begin{array}{c}\text { Контратака - все } \\
\text { финты }\end{array}$ & $\begin{array}{c}\text { Работа против ноги } \\
\text { - все финты }\end{array}$ & Атака - все финты & $\begin{array}{c}\text { Контратака - все } \\
\text { финты }\end{array}$ & $\begin{array}{c}\text { Работа против ноги } \\
\text { - все финты }\end{array}$ & Выходной \\
\hline
\end{tabular}


Таблица 3.

Результаты соревнований всероссийского и международного уровня с 2012 по 2021 год

\begin{tabular}{|c|c|c|c|}
\hline Год & Соревнования & Город & Результат \\
\hline 2012 & Кубок России & Орел & 1 золото, 1 серебро, 3 бронзы \\
\hline 2012 & Первенство России & Уфа & 1 золото, 1 бронза \\
\hline 2012 & Кубок Мира & Анапа & 1 золото, 1 серебро, 1 бронза \\
\hline 2013 & Кубок России & Самара & 2 бронзы \\
\hline 2013 & Кубок Мира по боевым искусствам & Феодосия, Украина & 2 золота, 2 серебра и бронза \\
\hline 2013 & Кубок Мира & Анапа & 1 золото, 2 серебра, 1 бронза \\
\hline 2013 & Олимпиада Боевых Искусств & Санкт-Петербург & 1 золото \\
\hline 2013 & Первенство России & Псков & 1 золото \\
\hline 2014 & Кубок России & Самара & 4 золота, 1 бронза \\
\hline 2014 & Олимпиада боевых искусств & Санкт-Петербург & 2 золота, 6 бронз \\
\hline 2014 & Кубок Мира & Сегед, Венгрия & 1 золото \\
\hline 2014 & Первенство Мира & Римини, Италия & 1 бронза \\
\hline 2014 & Первенство России & Серпухов & 5 серебра, 1 бронза \\
\hline 2015 & Кубок Европы & Карловац, Хорватия & 3 золота, 1 серебро, 1 бронза \\
\hline 2015 & Кубок России & Самара & 4 серебра, 4 бронзы \\
\hline 2016 & Первенство России & Алушта & 3 золота, 5 серебра, 6 бронз \\
\hline 2017 & Кубок Европы & Карловац, Хорватия & 4 золота, 1 серебро, 3 бронзы \\
\hline 2017 & Первенство России & Омск & 2 золота, 1 серебро, 1 бронза \\
\hline 2017 & Кубок Мира & Будапешт, Венгрия & 1 золото, 1 серебро \\
\hline 2017 & Кубок России & Самара & 2 золота, 6 серебра, 3 бронзы \\
\hline 2018 & Мировой турнир & Афины, Греция & 1 золото \\
\hline 2018 & Первенство России & Покровское, М0 & 2 золота, 2 серебра, 3 бронзы \\
\hline 2018 & Евразийские игры боевых искусств & $\mathrm{y}_{\phi а}$ & 1 золото, 2 серебра, 2 бронзы \\
\hline 2018 & Кубок Мира & Анапа & 2 серебра, 3 бронзы \\
\hline 2018 & Всероссийские игры боевых искусств & Анапа & 1 золото, 1 серебро, 2 бронзы \\
\hline 2018 & Кубок России & Омск & 3 золота, 2 серебра, 3 бронзы \\
\hline 2019 & Первенство России & Самара & 6 золота, 6 серебра, 1 бронза \\
\hline 2019 & Кубок Мира & Римини, Италия & 1 золото \\
\hline 2019 & Чемпионат Мира по боевым искусствам & Орландо, США & 1 золото \\
\hline 2020 & Кубок Европы & Конельяно, Италия & 3 серебра, 5 бронз \\
\hline 2020 & Кубок Мира & Дублин, Ирландия & 3 золота, 2 серебра, 2 бронзы \\
\hline 2021 & Первенство России & Челябинск & 1 золото \\
\hline 2021 & Кубок Европы & Белград, Сербия & 3 золота, 1 серебро \\
\hline
\end{tabular}

Для результативных занятий pointfighting необходимо постепенное освоение тактики боя с установкой на использование самых результативных связок и финтов $[4$, c.47].

В таблице 1 представлены эффективные атакующие, контратакующие действия и работа против ног в разделе поинтфайтинг.
Для эффективного овладения тактики кикбоксеры выполняют упражнения в парах 2 минуты со сменой номеров через каждые 30 секунд в 4 разных режимах: статистический, динамический, тактических и боевой.

1. Статистический режим - режим, где спортсмены выполняют упражнения в медленном режиме, отрабатывая правильность движения атаки или контратаки; 
2. Динамический режим - режим, где кикбоксеры выполняют упражнения в быстром режиме с места, отрабатывая скорость атаки или контратаки соперника;

3. Тактический режим - режим, где спортсмены выполняют все атакующий и контратакующие действия из движущего положения, используя всевозможные финты: финт ногой, stop-and-go, выпад, вход в зону;

4. Боевой режим - режим, где первый номер пытается через все возможные финты заработать балл, а второй номер вызвать на себя и контратаковать партнера, заработав балл первым.

Методика обучения тактики ведения боя в разделе поинтфайтинг представлена в таблице 2.

Полученные результаты с соревнований всероссийского и международного уровня в разделе поинтфайтинг представлены в таблице 3 с 2012 по 2021 год.

Анализ данных, представленных в таблице 3 доказывает, что кикбоксеры успешно выступают на соревнованиях всероссийского и международного уровня с использованием в тренировочном процессе методики обучения тактики ведения боя. Каждый год спортсмены привозят золотые, серебряные и бронзовые медали с кубков и первенств России, Европы, Мира, Мировых турниров, а также фестивалей боевых искусств.

\section{Выводы:}

1. Разработанная методика обучения тактики ведения поединка включает в себя пять недель разнонаправленных, однако максимально полно дополняющих друг друга тренировочных занятий, ориентированных на увеличении динамики освоения спортсмена компонентов тактической подготовки.

2. Особое внимание, акцентируемое на тактической подготовке спортсмена в условиях тренировочного процесса спортивной подготовки тренировке спортсменов в pointfighting обусловлено ростом спортивного мастерства соперников на мировой спортивной арене. В ходе исследования был выявлен наиболее уязвимый раздел спортивной подготовки кикбоксера, что позволило разработать эффективную методику преодоления препятствий на пути освоения спортсменом важных с точки зрения спортивных достижений техникотактических элементов.

3. Результаты, зафиксированные в ходе выступления спорстменов - участников опытно-экспериментальной части настоящего исследования, наглядно продемонстрировали результативность авторской программы подготовки, отразившись в завоевании 14 золотых медалей на первенстве России, 10 золотых медалей на кубке России, 10 золотых медалей на кубке Европы, 8 золотых медалей с кубка Мира и золото с мирового турнира. А так же 3 золотых медали на олимпиаде боевых искусств, 1 золотая медаль на Евразийских играх боевых искусств, 1 золотая медаль на всероссийских играх боевых искусств, 2 золотых медали на кубке Мира по боевых искусствам, а так же 1 золото на Чемпионате Мира по боевых искусствам.

Таким образом, увеличение тактической подготовки в разделе поинтфайтинг позволяет с успехом выступать на всероссийских и международных стартах.

\section{ЛИТЕРАТУРА}

1. Градополов К.В. Тактика бокса в приёмах зарубежных мастеров ринга [Текст] / К.В. Градополов. - М.: ЁЁ Медиа, 2014. - 457 с.

2. Гожин В.В. Теоретические основы тактики в спортивных единоборствах: Учебник. [Текст] / В.В. Гожин, 0.Б. Малков. - М.: ФиС, 2008. - 232 с.

3. Джероян Г.0. Тактическая подготовка боксера [Текст] / Г.О. Джероян. - М.: ЁЁ Медиа, 2017. - 655 с.

4. Джероян Г.О. Тактика бокса [Текст] / Г.О. Джероян // Бокс: Учебник для институтов физ. культ. - М.: ФиС, 2009. - 342 с.жероян Г.0. Тактическая подготовка боксера [Текст] / Г.0. Джероян. - М.: ЁЁ Медиа, 2017. - 655 с.

5. Иванов А.Л. Кикбоксинг [Текст] / А.Л. Иванов. - Киев: Книга-Сервис, Перун, 1995. - 312 с.

6. Потеряхин, А.А. Кикбоксинг. Татами-дисциплины: учебно-методическое пособие / А.А. Потеряхин, В.Л. Кондаков, И.Ю. Воронин. - Белгород: О00 «Эпицентр», 2020. - $160 \mathrm{c}$.

7. Ashley, S. Kickboxing [Tekct] / S. Ashley. - England: Lumina Press, 2011. - 139 p.

8. Falsoni, E. Kickboxing the phenomenology of a sport [Текст] / E. Falsoni, A. Micheli. - Milan: miolagrafiche s.r.l. 2011. - 205 p.

( П Потеряхин Алексей Андреевич (Kingmickey@mail.ru), Кондаков Виктор Леонидович (kondakov@bsu.edu.ru).

Журнал «Современная наука: актуальные проблемы теории и практики» 